WIELKIE TEMATY KULTURY W LITERATURACH SKOWIAŃSKICH

Slavica Wratislaviensia CLXVIII • Wrocław 2019•AUWr No 3875

DOI: $10.19195 / 0137-1150.168 .7$

Data przesłania artykułu: 2.10 .2017

Data akceptacji artykułu: 7.01.2018

RYSZARD KUPIDURA

Uniwersytet im. Adama Mickiewicza w Poznaniu, Polska

\title{
Między autotematyzmem a eksperymentem artystycznym - motyw śmierci dziecka w twórczości Mychajła Kociubynskiego i Wołodymyra Wynnyczenki
}

Mychajło Kociubynski i Wołodymyr Wynnyczenko to autorzy, których twórczość badacze chętnie porównują. Dzieje się tak najczęściej ze względu na odmienności (często antypodyczne) aniżeli na podobieństwa propozycji artystycznych w poszczególnych utworach. Już w 1912 roku krytyk Mychajło Mohylanski w podsumowaniu pierwszej dekady działalności literackiej Wynnyczenki, określając jego teksty jako chaotyczne i wewnętrznie sprzeczne, stwierdził, że mogą one stanowić jedynie kontrapunkt dla harmonijnej i przepełnionej estetyzmem prozy autora Intermezzo ${ }^{1}$.

Sami zainteresowani również nie stronili od wzajemnych porównań i jeśli wierzyć zapewnieniom znanego ówcześnie mecenasa ukraińskiej sztuki i literatury Jewhena Czykałenki, sam Kociubynski miał prosić go, aby ten ocenił jego twórczość w zestawieniu z dorobkiem młodszego kolegi ${ }^{2}$. Obaj autorzy w swoich utworach podejmują podobne problemy, między innymi dychotomię miasta i wsi, narastającą atmosferę rewolucyjną, emancypację kobiet czy stosunki etniczne w Imperium Rosyjskim, lecz każdy z nich robi to zazwyczaj w inny, często przeciwstawny drugiemu autorowi sposób. Dzieje się tak również wówczas, gdy w ich tekstach pojawiają się wątki tanatyczne. Obaj pisarze korzystają chętnie

${ }^{1}$ М. Могилянский, Кочюбинский и Винниченко, „Украинская жизнь” 1912, nr 6, s. 56-65.

${ }^{2}$ Н. Миронець, Володимир Винниченко: таємнииі кохання. Хронологія інтимів, Київ 2013, s. 36. 
ze swych demiurgicznych prerogatyw, by z zależnego od ich woli wyniku walki życia i śmierci uczynić ostateczny argument mający przekonać czytelników do głoszonych w ich utworach postulatów ideowych.

W 1895 roku coraz bardziej powątpiewający w słuszność programu narodnickiego Kociubynski pisze opowiadanie Для загального добра, w którym dowodzi, że ingerencji centrum w życie prowincji/kolonii niezmiennie towarzyszy przemoc, której efektem końcowym jest śmierć podporządkowanej jednostki. Ponad dwadzieścia lat później socjalista Wynnyczenko, tępiący w przededniu rewolucji pokutujące na ukraińskiej wsi zabobony, kreuje postać młodej lekarki (Баришенька, 1916), która korzystając z autorytetu centrum, wstrzymuje zabiegi wiejskich znachorek i ratuje życie dopiero co urodzonego dziecka i jego matki. W niniejszym opracowaniu porównany zostanie motyw śmierci dziecka, który zajmuje centralne miejsce zarówno w problematyce noweli Kwiat jabłoni (Цвim яблуні, 1902) Kociubynskiego, jak i dwóch dramatów Wynnyczenki - Memento (1909) oraz Чорна Пантера і Білий Ведмідь (1911).

Współcześni badacze twórczości Kociubynskiego klasyfikują jego nowelę Kwiat jabłoni z 1902 roku wraz z cyklem 3 глибини (1903) oraz bodaj najbardziej rozpoznawalnym dziełem impresjonisty — nowelą Intermezzo (1908) - do rzędu utworów autotematycznych ${ }^{3}$. Wydaje się jednak, że pomimo takiego uszeregowania i obszernej literatury przedmiotu nie wszystkie sygnały autotematyczności zostały w tym wypadku dokładnie rozpoznane i opisane. Ich lokalizacja i charakterystyka stanowi zatem dodatkowe zadanie niniejszego tekstu.

Jak wiadomo, autorstwo terminu ,autotematyzm” przypisuje się Arturowi Sandauerowi, który w swych pracach odróżniał sztuki autotematyczne (na przykład muzykę, taniec, architekturę) od sztuk heterotematycznych (takich jak malarstwo czy literatura). Z tym że, jak zauważył badacz, te dwie ostatnie mogą starać się rezygnować z komunikowania treści i znaczeń na rzecz zwrócenia się ku samym sobie jako rzeczywistościom samoistnym. W wypadku malarstwa nurt tego typu praktyk artystycznych został nazwany abstrakcjonizmem, w literaturze natomiast przyjął postać właśnie autotematyzmu ${ }^{4}$.

Wprowadzony przez Sandauera w połowie XX wieku termin nie opisywał zjawiska nowego w literaturze, tendencje autotematyczne były bowiem obecne w niej praktycznie od początku, a nasilały się zawsze w tych okresach, kiedy twórcy kładli nacisk na jej funkcję autoteliczną ${ }^{5}$ Trafność rozpoznania autora Samobójstwa Mitrydatesa oraz powszechność zjawiska autotematyzmu przy jednoczesnym zróżnicowaniu jego form spowodowały, że problem ten stał się dość

3 Я. Поліщук, I ката, і героя він любив... Михайло Коцюбинський. Літературний порmрет, Київ 2017, s. 84.

${ }^{4}$ A. Sandauer, Samobójstwo Mitrydatesa, [w:] idem, Liryka i logika, Warszawa 1971, s. 385386.

5 J. Cerazy, Literatura wyczerpania? - współczesny autotematyzm na podstawie „Do szpiku kości” Krzysztofa Jaworskiego, „Studia Filologiczne Uniwersytetu Jana Kochanowskiego” 28, 2015, cz. 2, s. 76, http://www.ujk.edu.pl/ifp/studia_filologiczne/?page_id=32 [dostęp: 20.07.2017]. 
popularny w polskich pracach literaturoznawczych i dzisiaj można mówić już o pewnej ustalonej tradycji badawczej ${ }^{6}$. Warto zaznaczyć, że została ona w części przetransferowana także na ukraiński obszar badań ${ }^{7}$, na którym to doszukiwano się tendencji autotematycznych w twórczości między innymi Mykoły Chwylowego, Majka Johansena, Ułasa Samczuka czy Oksany Zabużko ${ }^{8}$.

Wracając jednak do interesujących nas autorów, należy zwrócić uwagę, że napisane w 1908 roku Intermezzo wieńczy okres, który można by nazwać autotematycznym zwrotem w biografii literackiej Kociubynskiego. Prawomocność użycia terminu „zwrot”, sygnalizującego odcięcie się od przeszłości i całkowitą zmianę kierunku, zasadzałaby się $\mathrm{w}$ danym przypadku na tym, że chronologicznie Kwiat jabłoni jedynie o rok poprzedza próba stworzenia przez pisarza obszernego obrazu epickiego w postaci opowiadania Дорогою ціною (1901), utrzymanego w konwencji dziewiętnastowiecznej prozy historycznej z tradycyjną narracją, statycznymi opisami przyrody, linearną fabułą itp.

Początek XX wieku oznacza dla Kociubynskiego radykalne odejście od tej tradycji i skierowanie się w stronę indywidualnego stylu modernistycznego, który Jurij Kuzniecow nazwie później impresjonizmem psychologicznym9. Jak

${ }^{6}$ Zarys dyskusji nad zjawiskiem autotematyzmu przedstawiają Ewa Szary-Matywiecka oraz Joanna Grądziel-Wójcik; zob. E. Szary-Matywiecka, Autotematyzm, [w:] Stownik literatury polskiej XX wieku, red. A. Brodzka et al., Wrocław-Warszawa-Kraków 1992, s. 54-62; J. Grądziel-Wójcik, Perpetuum mobile, czyli kilka uwag o autotematyzmie, „Forum Poetyki” jesień 2015, s. 108-117, http://fp.amu.edu.pl/perpetuum-mobile-czyli-kilka-uwag-o-autotematyzmie/ [dostęp: 20.07.2017].

7 Stało się to głównie dzięki opublikowanemu w 1999 roku artykule Bogusława Bakuły Автор, автотематизм, автобіографізм, na który powołuje się większość badaczy śledzących oblicza autotematyzmu w literaturze ukraińskiej. Zob. Б. Бакула, Автор, автотематизм, автобіографізм, „Наукові Записки На УКМА: Філологія” 17, 1999, s. 88-91, http://1576.ua/ books/5938 [dostęp: 20.07.2017].

${ }^{8}$ С. Філоненко, Концепція особистості жінки в украйнській жіночій прозі 90-х років XX століття, Київ 2006; М. Цехмейструк, Автотематизм у структурі поетики мемуарно-автобіографічного ииклу Уласа Самчука, „Літературознавчі Обрії. Праці Молодих Учених" 18, 2010, s. 120-126, http://dspace.nbuv.gov.ua/bitstream/handle/123456789/38428/21-Tsekhmeistruk.pdf?sequence=1 [dostęp: 20.07.2017]; В. Саєнко, Діалогічність і автотематизм у новелістиці Миколи Хвильового, „Рідний Край” 2013, nr 1 (28), s. 80-83, http://dspace. pnpu.edu.ua/bitstream/123456789/1959/1/Sayenko.pdf [dostęp: 20.07.2017]; С. Рябчук, Автор i читач у повісті Майка Йогансена „Подорож ученого доктора Леонардо...”, http://mdeksperiment.org/post/20160519-avtor-i-chitach-u-povisti-majka-jogansena-podorozh-uchenogodoktora-leonardo [dostęp: 20.07.2017]. Wśród wymienionych autorów jedynie Oksana Zabużko należy do pokolenia tworzącego po 1991 roku, a to oznacza, że otwiera się szeroka perspektywa dla badań nad postaciami autotematyzmu w najnowszej literaturze ukraińskiej, których można się doszukiwać w twórczości m.in. J. Andruchowycza (Dwanaście kręgów [Дванадиятьь обручів, 2003], Leksykon intymnych miast [Лексикон інтимних міст, 2011]), J. Wynnyczuka (Весняні ігри в осінніх садах, 2005), O. Irwancia (Na żуwо [Прямий ефip, 1995]), S. Uszkałowa (БЖД, 2007), T. Malarczuk (Забутmя, 2016).

${ }^{9}$ Ю. Кузнецов, Імпресіонізм в українській прозі кіния XIX-початку XX ст. (проблеми естетики і поетики), Київ 1995, s. 147-226. 
możemy zaobserwować, sytuacji tej towarzyszy pogłębiona i uzewnętrzniona autorefleksja pisarska. W Kwiecie jabłoni oraz w Intermezzo Kociubynski wydziela kursywą kluczowe dla tych tekstów frazy. Odpowiednio są to: „Я не можу не слухати його” oraz „Я не можу бути самотнім”"10. Impresjonista deklaruje w nich zarówno swą postawę artystyczną, polegającą na permanentnym przetwarzaniu na język sztuki bodźców pochodzących z rzeczywistości pozaliterackiej, jak i postawę ideową, gdyż niezależnie od ewolucji stylu literackiego pisarz pozostaje wrażliwy na problemy społeczne ${ }^{11}$. Drugi postulat nie musiał obligatoryjnie wykluczać tendencji autotematycznych. Jak bowiem zauważył Julian Przyboś: „Dzieło dla dzieła, książka dla książki [...] nie znaczy zawsze i koniecznie: sztuka dla sztuki"12.

Wolta Kociubynskiego z początku stulecia ciekawie koresponduje też z opinią autora Pałuby - Karola Irzykowskiego, który wypowiadając się o ograniczeniach autotematyzmu, posłużył się figurą magika, który po wyczerpaniu wszystkich swoich trików organizuje ostatnie przedstawienie, by odsłonić swój warsztat $^{13}$. Autor Intermezzo czyni dokładnie odwrotnie, już na samym początku ujawniając przed czytelnikami sekrety własnej prozy.

Kwiat jabłoni nie jest tym samym spowiedzią pisarza ze stanu niemocy twórczej. Wprost przeciwnie - nowela stanowi świadectwo erupcji talentu, której totalny charakter w równej mierze ekscytuje i przeraża głównego bohatera. Jest on jednocześnie zaskoczony i zawstydzony swą postawą w obliczu sytuacji ostatecznej. Autentyczne zdziwienie wywołuje u niego spostrzeżenie, że agonia bliskiej sercu osoby nie powoduje zawężenia percepcji i że wciąż potrafi dostrzec między innymi naruszające symetrię przesunięcie zawieszonej na ścianie fotografii, a pogrążona w żałobie żona nie przestaje wzbudzać w nim erotycznego pożądania.

Interesujące, szczególnie w kontekście niniejszego zestawienia z dramaturgią Wynyczenki, wydaje się także pytanie o biograficzny kontekst powstania noweli. Polskiego czytelnika tekstów ukraińskiego impresjonisty ze względu na rodzimą tradycję literacką niejako odruchowo powinna zainteresować kwestia, czy Kociubynskiemu z autopsji znane było doświadczenie śmierci dziecka. Kwestia ta jest dyskusyjna, brakuje bowiem świadectw, które jednoznacznie potwierdzałyby autentyczność takiego zdarzenia. A to oznacza, że brak bezpośredniego odniesienia do biografii autora będzie dodatkowo wyróżniał Kwiat jabłoni spośród pozostałych utworów Kociubynskiego, które w znakomitej większości powstawały jako literacka transformacja przeżytego doświadczenia ${ }^{14}$.

Przedstawienie działań pisarza jako postaci literackiej w świecie fikcyjnym bez afiszowanego autobiografizmu — co ma miejsce w Kwiecie jabłoni — można

${ }^{10}$ Cyt. za: ibidem, s. 177.

11 М. Моклиця, Модернізм у творчості письменників ХХ століття, Луцьк 1999, s. 52.

12 Cyt. za: B. Bakuła, Oblicza autotematyzmu (autorefleksyjne tendencje w polskiej prozie po roku 1956), Poznań 1991, s. 11.

13 Cyt. za: ibidem, s. 69.

14 Я. Поліщук, I ката, і героя він любив..., s. 33. 
nazwać za Bogusławem Bakułą autotematyzmem fingowanym ${ }^{15}$ lub — odwołując się do innych propozycji terminologicznych, pojawiających się w dyskusji nad autorefleksją literacką - literaturą warsztatową ${ }^{16}$.

Zauważmy także, że autotematyzm może być pojmowany zarówno w szerokiej konotacji - jako zbiór wszystkich sygnałów i sytuacji autotematycznych obecnych w tekście, jak i wąskiej — jako sensu stricto tekst autotematyczny, w którym centralnym ośrodkiem w strukturze jest autorefleksja odnosząca się do tworzonego dzieła ${ }^{17}$.

Z jednej strony podczas lektury Kwiatu jabłoni nie znajdujemy refleksji pisarskiej nad procesem tworzenia tego konkretnego utworu, z drugiej jednak nowela anonsuje powstanie wielu innych utworów, zawieszonych niejako w stanie in potentia. „Чому б мені не взяти такої ночі до того епізоду розпочатого мною роману, де Христина, покинувши свого чоловіка, опинилась раптом із великого города у глухому містечку?" - zastanawia się już na początku utworu narrator-bohater. W dalszych partiach tekstu regularnie wspominany jest odkładający się w pamięci „materiał” do przyszłej pracy literackiej. Tym samym mamy do czynienia z intertekstualnością autotropiczną, czyli sytuacją, w której utwór ,eksponuje dzieła swojego autora sfingowane lub niezaistniałe, będące projektami, pisarskim marzeniem" 18 .

Typowa dla tekstów autotematycznych narracja pierwszoosobowa prowadzona w formie spowiedzi ma w noweli dodatkową funkcję terapeutyczną, która nie pozwala bohaterowi ostatecznie pogrążyć się w rozpaczy. Aktualizujące się wciąż na nowo napięcie między przeżywaniem a opisywaniem przeżywania stwarza iluzję przebywania na zewnątrz sytuacji traumatycznej, co z jednej strony pozwala być podporą dla innych domowników, z drugiej jednak rodzi poczucie przewiny i zawstydzenia.

Dominująca w warstwie narracyjnej technika monologu wewnętrznego, ciążąca miejscami ku strumieniu świadomości ${ }^{19}$, stanowi jeden z podstawowych wyróżników poetyki impresjonizmu psychologicznego, którą anonsuje Kociubynski w Kwiecie jabłoni. Do pozostałych jej cech należą między innymi:

- animizacja emocji i światłocienia („Нi, дім не спить. У ньому живе щось велике, невідоме. Я чую, як воно дихає, зітхає, як неспокійно калатає його серце і б’ється живчик. Я знаю - то тривога” 20 oraz „В її головах горить світло. Се чудне, неприродне, бліде, мов мертве, світло серед білого дня. Тремтячим блиском воно цілує мертві щічки" ${ }^{21}$ );

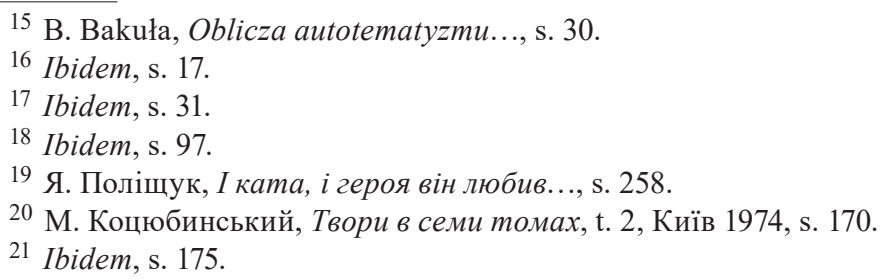


- eksponowanie autotelicznej funkcji języka, utrudnione - jak wiadomo - w gatunkach prozatorskich, osiągane przez Kociubynskiego między innymi poprzez odwołanie się do zjawiska satiacji semantycznej (,„»Гідрохінон... гідрохінон... гідрохінон...« Чогось се слово мені вподобалося, і я повторяю його 3 кождим кроком і боюсь пропустити в йому якийсь склад"22);

— synestezyjne opisy otaczającej rzeczywistości, wyrażane niekiedy poprzez synekdochę (,„звінки впали мені на голову”23, „вікно сіріє”24);

— symboliczna stylizacja pejzażu ${ }^{25}$;

— aktualny chronotop, odnoszący się do rzeczywistości tu i teraz ${ }^{26}$;

— afabularność tekstu;

— zacieranie się cech różnicujących w triadzie bohater-narrator-autor.

Zauważmy, że choć w Kwiecie jabłoni nie spotykamy charakterystycznej dla tekstów autotematycznych demaskacji literatury, mamy tu jednak do czynienia z wyraźną demitologizacją statusu pisarza. Talent pisarski traci w tym wypadku swoją tradycyjną konotację z powołaniem i staje się czymś na kształt wstydliwej przypadłości, niemalże utożsamianej z jednostką chorobową. Kociubynski w noweli nie odsłania przed czytelnikiem tekstowych rusztowań, na których wznosi się utwór. Gdyby tak było, wówczas nieodzownie światło dzienne musiałby ujrzeć fakt, że kwestia ewentualnego wyzdrowienia dziewczynki leży wyłącznie w kompetencjach autora, a obecny w tekście lekarz kapituluje w istocie nie wobec choroby, lecz wobec woli swojego stwórcy. Ostentacyjne uśmiercanie i wskrzeszanie bohaterów pojawi się dopiero w Подорожі ученого доктора Леонардо і його майбутньої коханки прекрасної Альчести у Слобожанську Швайцарію (1928) Johansena. Tymczasem u Kociubynskiego śmierć dziecka nie podlega negocjacjom, jest śmiercią — jeśli można tak to określić — intencjonalnie realistyczną, z wszelkimi tego konsekwencjami. Pakt fikcyjny nie ulega zawieszeniu. A wszystko to po to, by uwypuklić podjęty w noweli problem moralny. Cierpienia i dylematy pisarza (to jest bohatera) w obliczu obnażonej umowności zdarzeń literackich nabrałyby cech groteski. Kwestia etyczna góruje zatem nad chęcią zaprezentowania czytelnikowi przeżyć doznawanych podczas aktu twórczego, choć jednocześnie jest z nimi nierozerwalnie związana. Zdanie kończące nowelę: „Моя мила донечко, ти не гніваєшся на мене?”27, którego brzmienie i umiejscowienie w tekście Kociubynski zaplanował już na etapie konspektowania utworu ${ }^{28}$, ustanawia ostateczną hierarchię ważności. Ów problem etyczny

22 Ibidem, s. 171.

23 Ibidem.

${ }^{24}$ Ibidem, s. 172.

${ }^{25}$ E. Wiśniewska, O sztuce pisarskiej Mychajła Kociubyńskiego, Wrocław-Warszawa-Kraków 1973, s. 72-96.

${ }^{26}$ Ю. Кузнецов, Імпресіонізм в украӥнській прозі..., s. 163.

${ }^{27}$ М. Коцюбинський, Твори в семи томах..., s. 176.

${ }^{28}$ Ibidem, s. 346. 
rozwinie Wołodymyr Wynnyczenko w swych dramatach Memento (1909) oraz Чорна Пантера і Білий Ведмідь (1911).

Zanim jednak o nich będzie mowa, zaznaczmy na wstępie, że wątki tanatyczne, w tym obrazy śmierci dziecka, pojawiają się również w małej prozie Wynnyczenki (Кумедія з Костем [1910], Федько-халамидник [1913]), utrzymanej przeważnie w duchu dziewiętnastowiecznej nowelistyki, w której motyw śmierci a priori niewinnego dziecka był wykorzystywany w celu demaskacji nierówności społecznych. Jak pisze Wołodymyr Panczenko: „Винниченко був різним у залежності від літературного роду чи жанру, в яких працював. У новелістиці він загалом залишався традиційним..."29. Dopiero w powieściach oraz gatunkach scenicznych Wynnyczenko najpełniej przejawiał swój talent eksperymentatora.

Eksperyment artystyczny w okresie modernizmu bywał często sojusznikiem praktyk autotematycznych, jednak w omawianych dramatach Wynnyczenki ślady autotematyczne nie są tak wyraziste jak przedstawione autorefleksyjne zabiegi Kociubynskiego i ujawniają się jedynie w wygłaszanych przez bohaterów poglądach na temat statusu sztuki i powinności artysty. To stanowczo za mało, by móc rozpatrywać te dzieła z perspektywy ustaleń teoretycznych z zakresu autotematyzmu. Dramaturg nie zdradza ani swej obecności, ani swego uprzywilejowanego statusu twórcy. Śmierć dziecka, podobnie jak w wypadku noweli Kociubynskiego, jest zależna od czynników obiektywnych bądź woli samych bohaterów.

Intrygujący jest natomiast kontekst autobiograficzny powstania pierwszego $\mathrm{z}$ wymienionych dramatów. Przedstawiony w Memento problem niechcianej ciąży zakończony tragicznym finałem, w którym ojciec przyczynia się do śmierci syna, jest w istocie zaadaptowaną na potrzeby sceniczne historią romansu Wynnyczenki z Lusią Goldmerstein. Jak wykazała Nadija Myroneć, niektóre fragmenty korespondencji kochanków zostały niemal w całości odtworzone w dialogach bohaterów dramatu ${ }^{30}$. Badaczka nie wyklucza również możliwego udziału pisarza $\mathrm{w}$ przedwczesnej śmierci syna, która zbiegła się z momentem publikacji Memento $^{31}$.

Dla Wynnyczenki twórczość literacka stanowiła laboratorium artystyczne, w którym przeprowadzał on eksperymenty mające na celu konfrontację postulatów nowej moralności z sytuacją życiową ${ }^{32}$. Autorska koncepcja modernistycznego systemu etycznego autora Сонячної машини nosiła nazwę „uczciwość ze sobą” (ukr. „чесність з собою”) i zdradzała podwójną socjalistyczno-nietzsche-

29 В. Панченко, Будинок з химерами: творчість Володимира Винниченка 1900-1920 рр. у європейському літературному контексті, Кіровоград 1998, s. 232.

${ }^{30}$ Н. Миронець, Володимир Винниченко..., s. 48-58.

31 Ibidem, s. 99-100.

32 Д. Гусар-Струк, Винниченкова моральна лябораторія, „Сучасність” 1980, nr 7-8, s. 97, http://diasporiana.org.ua/wp-content/uploads/books/3114/file [dostęp: 20.07.2017]. 
ańską proweniencję ${ }^{33}$. W interesujących nas dramatach Wynnyczenko sprawdza, czy jego protagoniści, będący nosicielami nowych idei moralnych, pozostaną im wierni, w sytuacji gdy:

- pojawia się czynnik radykalnie zmieniający ich dotychczasowe życie, który jednocześnie nie jest pochodną ich świadomego wyboru (kwestia niechcianej ciąży w Memento);

— dochodzi do konfliktu wykonywanych ról życiowych (wybór pomiędzy służeniem sztuce a powinnościami wobec rodziny w Чорній пантері...).

Eksperymenty Wynnyczenki ani $\mathrm{w}$ danych przypadkach, ani $\mathrm{w}$ innych utworach nie przynoszą zazwyczaj przejrzystych rozstrzygnięć. Pisarz prezentuje różne poglądy, często sprzeczne z sobą, a pytanie o możliwość społecznej implementacji założeń „uczciwości ze sobą” najczęściej pozostawia otwarte ${ }^{34}$. Współczesna pisarzowi krytyka postrzegała dysharmonijność twórczości Wynnyczenki przede wszystkim jako wadę, odmawiając jej potencjału artystycznego. Publiczność oczekiwała bowiem od autora, aby tworzył konstrukcje idealne, a nie demaskował wewnętrzne sprzeczności wyznawanych przez siebie koncepcji moralnych i społecznych ${ }^{35}$.

Zwróćmy jeszcze uwagę na tematyczne podobieństwa noweli Kociubynskiego oraz Чорної пантери... Wynnyczenki, w których odbywa się analogiczna realizacja wątków tanatycznych. Uchwycenie obrazu przebywającego w stanie agonalnym dziecka, które staje się największym pragnieniem artysty Kornija, w wypadku bohatera Kwiatu jabłoni przeradza się w niezależną od jego woli kompetencją. Mało wiemy o efekcie końcowym wysiłków pierwszego z nich. Szczątkowe dane sprowadzają się jedynie do deklaracji artysty, wyrażanych w formie gotycystycznych oksymoronów typu: „чудова блідність”36, zdradzających neronistyczne usposobienie Kornija. W pewnym sensie jego postać aktualizuje również mit o Orfeuszu, który płaci najwyższą cenę za ujrzenie tego, co zabronione. W dramacie Tanatos triumfuje po wielokroć, gdyż w scenie końcowej śmierć ponosi cała rodzina artysty.

To, co pozostaje nieuchwytne w dramacie Wynnyczenki, udaje się pochwycić bohaterowi Kwiatu jabłoni. Przy czym ,udaje się" wbrew jego intencjom, co stanowi swego rodzaju okoliczność łagodzącą. Fragmenty opisujące odchodzącą ku wieczności dziewczynkę mogą służyć jednocześnie jako świadectwo syn-

33 В. Панченко, Творчість Володимира Винниченка 1902-1920 рp. у генетичних і типологічних зв'язках з європейскими літературами, http://library.kr.ua/books/panchenko/ [dostęp: 20.07.2017].

34 О. Філатова, Художні експерименти В. Винниченка: конфлікт духовного й тілесного, „Науковий вісник Миколаївського Державного Університету Імені В. О. Сухомлинського. Серія: Філологічні Науки” 12, 2013, nr 4, s. 230-235, http://litzbirnyk.com.ua/wp-content/ uploads/2013/12/4-12-50.pdf [dostęp: 20.07.2017].

35 Д. Гусар-Струк, Винниченкова моральна..., s. 105.

36 В. Винниченко, Оповідання. Слово за тобою, Сталіне! Чорна Пантера і Білий Медвідь, Київ 2001, s. 242. 
kretycznego charakteru impresjonistycznej poetyki Kociubynskiego, w której literatura koresponduje z innymi dziedzinami sztuki, między innymi z muzyką, a nade wszystko z malarstwem ${ }^{37}$. Oddajmy zatem na koniec głos jednemu z najwybitniejszych dwudziestowiecznych stylistów ukraińskich:

Посеред хати, на великому подвійному ліжку, на білих ряднах, лежить моє кришенятко, уже посиніле. Ще дихає. Слабий свист вилітає крізь спечені уста і дрібні зубки. Я бачу скляний уже погляд напівзакритих очей, а мої очі, мій мозок жадібно ловлять усі деталі страшного моменту... і все записують... I те велике ліжко з маленьким тілом, і несміливе світло раннього ранку, що обняло сіру ще хату... і забуту на столі, незгашену свічку, що крізь зелену умбрельку кидає мертві тони на вид дитини... і порозливану долі воду, і блиск свічки на пляшці з лікарством... Щоб не забути... щоб нічого не забути... ні тих ребер, що з останнім диханням то піднімають, то опускають рядно... Ні тих, мертвих уже, золотих кучерів, розсипаних по подушці, ані теплого запаху холодіючого тіла, що наповняє хату... 38

\section{Bibliografia}

Bakula B., Avtor, avtotematyzm, avtobiografizm, „Naukovi Zapysky Na UKMA: Filologija” 17, 1999, http://1576.ua/books/5938.

Bakuła B., Oblicza autotematyzmu (autorefleksyjne tendencje w polskiej prozie po roku 1956), Poznań 1991.

Cerazy J., Literatura wyczerpania? - współczesny autotematyzm na podstawie „Do szpiku kości” Krzysztofa Jaworskiego, „Studia Filologiczne Uniwersytetu Jana Kochanowskiego” 28, 2015, cz. 2, http://www.ujk.edu.pl/ifp/studia_filologiczne/?page_id=32.

Filatova O., Hudozhni eksperymenty V. Vynnychenka: konflikt duhovnogoj tilesnogo, „Naukovyj Visnyk Mykolai'vs'kogo Derzhavnogo Universytetu Imeni V. O. Suhomlyns'kogo. Serija: Filologichni Nauky" 12, 2013, nr 4, http://litzbirnyk.com.ua/wp-content/uploads/2013/12/4-12-50.pdf.

Grądziel-Wójcik J., Perpetuum mobile, czyli kilka uwag o autotematyzmie, „Forum Poetyki” jesień 2015, http://fp.amu.edu.pl/perpetuum-mobile-czyli-kilka-uwag-o-autotematyzmie/.

Gusar-Struk D., Vynnychenkova moral'na ljaboratorija, „Suchasnist”” 1980, nr 7-8, http://diasporiana.org.ua/wp-content/uploads/books/3114/file.

Kocjubyns'kyj M., Tvory v semy tomah, t. 2, Kyi'v 1974.

Kuznecov Ju., Impresionizm v ukrai'ns'kij prozi kincja XIX-pochatku XX st. (problemy estetyky i poetyky), Kyi'v 1995.

Mogilyanskii M., Kotsyubinskii i Vinnichenko, „Ukrainskaya Zhizn” 6, 1912.

Moklycja M., Modernizm u tvorchosti pys'mennykiv XX stolittja, Luc'k 1999.

Myronec' N., Volodymyr Vynnychenko: tajemnyci kohannja. Hronologija intymiv, Kyi'v 2013.

Panchenko V., Budynok z hymeramy: tvorchist' Volodymyra Vynnychenka 1900-1920 rr. u jevropejs'komu literaturnomu konteksti, Kirovograd 1998.

Panchenko V., Tvorchist' Volodymyra Vynnychenka 1902-1920 rr. u genetychnyh i typologichnyh, $z v^{\prime}$ jazkah z jevropejskymy literaturamy, http://library.kr.ua/books/panchenko/.

Polishchuk Ja., I kata, i geroja vin ljubyv... Myhajlo Kocjubyns'kyj. Literaturnyj portret, Kyi'v 2017. Sandauer A., Liryka i logika, Warszawa 1971.

Szary-Matywiecka E., Autotematyzm, [w:] Stownik literatury polskiej XX wieku, red. A. Brodzka et al., Wrocław-Warszawa-Kraków 1992.

Vynnychenko V., Memento, http://chtyvo.org.ua/authors/Vynnychenko/Memento/.

${ }^{37}$ Ю. Кузнецов, Імпресіонізм в украӥнській прозі..., s. 224.

${ }^{38}$ М. Коцюбинський, Твори в семи томах..., s. 173-174.

Slavica Wratislaviensia 168, 2019

(C) for this edition by CNS 
Vynnychenko V., Opovidannja. Slovo za toboju, Staline! Chorna Pantera i Bilyj Medvid', Kyi'v 2001.

Wiśniewska E., O sztuce pisarskiej Mychajła Kociubyńskiego, Wrocław-Warszawa-Kraków 1973.

\section{Between self-reference and artistic experiment: The motif of a child's death in the literary works of Mykhailo Kotsiubynsky and Volodymyr Vynnychenko}

\section{Summary}

Mykhailo Kotsiubynsky and Volodymyr Vynnychenko had two opposing types of creative personalities. According to many scholars, Kotsiubynsky was a representative of the Apollonian element of Ukrainian culture, while Vynnychenko embodied the Dionysian. The author of this article focuses on the role of the motif of a child's death in their works and argues that in the case of Kotsiubynsky, the death of a child triggers his confession, while for Vynnychenko it functions as an opportunity to conduct an artistic experiment.

Keywords: Ukrainian literature, death, modernism, child, self-reference, impressionism

\section{Між автотематизмом та художнім експериментом - мотив смерті дитини у творчості Михайла Коцюбинського та Володимира Винниченка}

Резюме

Михайло Коцюбинський та Володимир Винниченко належать до двох протилежних типів творчих особистостей. За деякими дослідниками, перший презентує аполлонійське начало української культури, водночас другий — діонісійське. У статті автор простежить, яку функцію в їхній творчості виконує тема смерті дитини. У випадку Коцюбинського вона буде поштовхом до авторської сповіді, натомість для автора Чесності з собою загибель безневинного немовляти стане приводом для художніх експериментів.

Ключові слова: українська література, смерть, модернізм, дитина, автотематизм, імпресіонізм 